\title{
FUTURE OF THE AIRCRAFT INDUSTRY IN BRITAIN
}

\begin{abstract}
T a statement regarding the Government's future policy for research and development in the aircraft industry made in the House of Commons on May 13, the Minister of Supply, Mr. Aubrey Jones, said that, like the aircraft industries of other countries, the British industry has from its early days been supported by work done in Government establishments in connexion with defence and has developed with the help of Government contracts for research, development and production. Although the current reduction in defence demands will inevitably entail some contraction in the size of the industry, the Government will continue, as necessary, to sponsor and finance aeronautical research and development to meet defence requirements for aircraft and guided weapons. The industry has also been making a valuable contribution to the general economy of the country and to technological progress, and it has received material help from research undertaken under Government auspices primarily for defence purposes. So long as the achievements of the industry justify the expenditure, the Government intends to continue to make a financial contribution to aeronautical research in the field of civil transport, where this is not already covered by defence research.

The Government expects that the industry will progressively assume financial liability for this research, but considers it is also necessary for the industry to reorganize itself to meet the changed conditions and ensure that, in general, the industry is able increasingly to finance the development of
\end{abstract}

new civil projects without Government assistance. The Government will, however, be prepared to consider individual applications for development assistance on their merits. Amplifying this, Mr. Jones said that research is being undertaken into the possibility of a supersonic civil transport, and if the research develops to a point where an aircraft manufacturer begins to develop a selected design, the Government will consider, in the light of circumstances then obtaining, the possibility of a Government contribution.

The Royal Aircraft Establishment at Farnborough will continue research for military and civil aircraft, both manned and unmanned, and into subsonic as well as supersonic flight. The broad intention is to continue aeronautical research on about the present scale, and Mr. Jones emphasized that the demand for military aircraft is subsiding, but that hitherto military and civil research has been conducted as a whole. As civil research becomes more and more identifiable, the cost of that research will in course of time be passed on to the industry, although the research may still be conducted in a Government establishment. There are no grants to specific firms; the practice has been to contribute to the development of a civil aircraft and thereafter to exact a levy on the sales of that aircraft. Investment in normal aircraft on the part of the Government will cease, but when it comes to future aircraft embodying a great technological advance, the Government will consider the possibility of some help in the light of the particular circumstances.

\section{THE ROYAL AERONAUTICAL SOCIETY}

\author{
AWARDS FOR $1957-58$
}

\begin{abstract}
$\mathrm{T}$ HE following awards have been made by the Royal Aeronautical Society : Honorary Fellowship to Sir Richard Southwell and Honorary Companionship to Mr. W. E. Nixon; The Society's Gold Medal (the highest honour the Society can confer) to Sir Sydney Camm, director and chief designer, Hawker Aircraft, Ltd., for his outstanding achievements in aircraft design and development; The Society's Silver Medal to Dr. P. B. Walker, Air-worthiness Department, Royal Aircraft Establishment, Farnborough, for his distinguished contributions to aircraft structural integrity; The Society's Bronze Medal to Dr. D. Williams, for his contributions to the theory of aeroelasticity; The British Gold Medal for Aeronautics, to Mr. S. D. Davies, managing director, Dowty Fuel Systems, Ltd., for his outstanding practical work in the design and development of delta-winged aircraft; The British Silver Medal for Aeronautics to Mr. W. H. Lindsey and Mr. W. F. Saxton, both of Armstrong Siddeley Motors, Ltd., for their practical contributions to the development of aircraft gas turbines; The Wakefield Gold Medal to Mr. W. Tye, chief technical officer, Air Registration Board, for his great contribution to the air-worthiness of British civil aircraft; The R.P. Alston Medal to Mrs. Anne Burns, Structures Department, Royal Air-
\end{abstract}

craft Establishment, Farnborough, for her practical contributions to aireraft safety as a flight test observer; The N.E. Rowe Medal to Mr. P. A. Champion, of Bristol Aircraft, Ltd., for his paper on the design of supersonic wind tunnels; The Simms Gold Medal to Mr. L. F. Nicholson, head of the Aerodynamics Department at the Royal Aircraft Establishment, Farnborough, for his paper on engineairframe integration; The George Taylor (Australia) Gold Medal to Mr. R. L. Lickley and Mr. L. P. Twiss for their paper, "The Fairey Delta 2" (Mr. Lickley, formerly professor of aircraft design at the College of Aeronautics, Cranfield, is now technical director of the Fairey Aviation Company, Ltd. Mr. Twiss is chief test pilot of the Fairey Aviation Company, Ltd., and was the holder, during March 1956-December 1957 , of the world speed record of 1,132 m.p.h. in the Fairey Delta 2); The Edward Busk Memorial Prize to Dr. D. Kuchemann, a senior principal scientific officer at the Royal Aircraft Establishment, Farnborough, for his paper on methods of reducing the transonic drag of swept-back wings at zero lift; The Orville Wright Prize to Prof. A. R. Collar, professor of aeronautical engineering in the University of Bristol, for his paper, "On the Stability of Accelerated Motion-Some Thoughts on Linear Differential 
Equations with Variable Coefficients", published in The Aeronautical Quarterly; The Herbert Ackroyd Stuart Memorial Prize to Dr. R. R. Jamison, assistant chief engineer in charge of ram jets at the Bristol Aero-Engine Company, Ltd., for his paper on ramjets; The J.E. Hodgson Prize to Prof. H. J. van der Maas, professor of aeronautical science in the University of Delft, for his paper on aeronautical research in the Netherlands; The Branch Prize for 1958 has been awarded for the Roy Chadwick Memorial Lecture, read before the Manchester Branch in May 1957 by Mr. M. B. Morgan, one of the two deputy directors of the Royal Aircraft Establishment, Farnborough, on "Some Thoughts on Aeronautical Research and Design"; The Navigation Prize to Mr.
W. Makinson and Mr. G. M. Hellings for their paper on synthetic aids to flying training (Mr. Makinson is managing director and Mr. Hellings is chief engineer of Air Trainers Link, Ltd.); The Usborne Memorial Prize to Mr. D. G. Drake, lecturer in the Department of Aeronautical Engineering at the University of Southampton, for his paper, "The Oscillating TwoDimensional Aerofoil between Porous Walls", pub. lished in The Aeronautical Quarterly. Sir Arnold Hall, director of the Hawker-Siddeley Group, took office as president of the Royal Aeronautical Society at the conclusion of its annual general meeting on May 8, in succession to Sir George Edwards, managing director of Vickers-Armstrongs (Aircraft), Ltd.

\section{THE NATURE CONSERVANCY}

$\mathrm{T}$ HE eighth annual report of the Nature Con. servancy* covers the year ended September 30, 1957; and the shift in emphasis in the work of the Conservancy towards the execution of its research programme, the application of ecological and other acquired or currently emerging knowledge and the improvement of its educational and other advisory services noted in the previous report was maintained. The year's experience gives further point to the hope expressed in the concluding words of that report that the Conservancy's findings would demonstrate that, where the land is concerned, long views are sound views. The need for the Conservancy has been repeatedly demonstrated during the year, and effective backing has still to be won for a comprehensive long-term epproach in which, in the light of expanding scientific knowledge, the conservation of the natural resources of plant and animal life in Britain can be blended with tradition and with economic and other national considerations in policies of land use and land management. The Nature Conservanoy has sometimes been pressed to fall in with particular current attitudes and practices which it has reason to believe to be unsound, and it should be assured of the support of all scientists in refusing to trim its scientific findings and management plans to satisfy sectional and opportunist views. As the report rightly concludes, conservation is for all time, and should not be continually subordinated to issues of expediency which hold only for a decade or two or even less.

The report shows that there are need and opportunity for much more clearly expressed support of the work of the Conservancy by scientists in general, and by all those who care for the ideas which the Conservancy represents. Close liaison with the Central Electricity Authority has enabled the Conservancy to avert several collisions, and the nuclear power programme has gone ahead without delay, and so far with a minimum of damage to the fauna and flora and to important physiographical features; although the pace of current development of agriculture, forests, highways, airfields, defence installations, nuclear power stations, extraction of minerals, oil refineries and pipelines has necessitated many hasty decisions involving irreversible consequences

* Report of the Nature Conservancy for the year ended 30th September 1957. Pp. $v+99+13$ plates. (London: H.M. Stationery for the land and its natural resources of soil, water and animal and plant life. The liaison established on St. Kilda has minimized and not eliminated damage from developments necessitated by the Hebridean Guided Missiles project and no more can be claimed or expected from the consultations over developments at Milford Haven.

It is the more urgent and important accordingly to accelerate the basic and applied research programmes, the result of which may determine the choice between wise decisions giving satisfactory long-term results, and ill-judged decisions which our descendants, if not ourselves, may have cause to regret. While the grant-in-aid for the current financial year (1957-58) has again been increased, practically all this $£ 30,000$ will be absorbed by the effects of inflation, and the resources devoted to research are not yet in any way commensurate with their importance or with the scale of economic and other losses which may result from continuing to settle such matters largely in the dark. Of the total grant. in-aid for $1956-57$ of $£ 280,000, £ 54,000$ was in respect of capital expenditure, and the Conservancy is still unable to meet adequately the expenditure needed for the proper maintenance and management of nature reserves or to make new research grants, although six were extended and ten postgraduate research studentships awarded and sixteen continued.

Besides this, the Conservancy urges that there is still too little appreciation of the damage being done, even to the national nature reserves, by visitors who ignore the importance of safeguarding the bare minimum of strongholds in which the hard-pressed fauna and flora can survive as a permanent part of the national heritage. The need for undisturbed experimental areas where the scientific programme can be carried out without interruption or disturbance is even less widely recognized. Further, there is no national body of citizens who recognize their responsibility to guide, stimulate and educate opinion on the importance of nature reserves.

During 1956-57, the acreage of national nature reserves rose by the acquisition of nine new reserves from 82,662 to 121,825 , including the Hebridesn islands of Rhum and St. Kilda. Encouraging progress was made by the newly organized Conservation Branch in preparing detailed management plans for nature reserves and in reorganizing the warden 